\title{
COMPARATIVE STUDY OF THE ENDOCRINE DISORDERS OF BETA- THALASSEMIA MAJOR PATIENTS AND CONTROL GROUP IN DUHOK PROVINCE
}

\author{
Ghorbat Saleh Ali ${ }^{\mathrm{a}, *}$, Amad M. Saleh Jubrial ${ }^{\mathrm{b}}$, Malika Kassem Najeeb ${ }^{\mathrm{c}}$, Hamdia Y. Issa Al hussein ${ }^{\mathrm{d}}$ \\ a Faculty of Science, University of Duhok, Kurdistan Region, Iraq - ghorbat.ali@uod.ac \\ ${ }^{\mathrm{b}}$ Faculty of Science, University of Duhok, Kurdistan Region, Iraq- amadsofi@gmail.com \\ ${ }^{c}$ Faculty of Science, University of Duhok, Kurdistan Region, Iraq- malika kassim2007@yahoo.com \\ d Faculty of Science, University of Zakho, Kurdistan Region, Iraq- hamdia.alhussein@uoz.edu.krd
}

Received: Aug. 2018 / Accepted: Dec., 2018 / Published: Dec., 2018

https://doi.org/10.25271/sjuoz.2018.6.4.539

\begin{abstract}
:
Beta- thalassemia major is a type of inherited blood disorder, characterized by impaired synthesis of the beta chains. Currently, blood transfusion and sufficient iron chelation therapy are important for treatment and follow up of thalassemia patients. Unfortunately, repeated blood transfusion causes the progressive iron overload. Consequently, the excess iron is deposited as hemosiderin and ferritin in the tissues and multiple endocrine complications. In comparison with healthy control group, the results indicated significant $(\mathrm{p}<0.05)$ increased TSH level $(3.86 \pm 2.71 \mu \mathrm{IU} / \mathrm{ml})$, whereas the serum level of T4 hormone did not significantly differ between the two groups. In the thalassemia patients, $23.68 \%(9 / 38)$ had subclinical hypothyroidism. The mean level of estradiol in patients $(30.60 \pm 14.68 \mathrm{pg} / \mathrm{ml})$ is high significant $(\mathrm{p}<0.01)$ decreased that compared with the control persons $(13.83 \pm 9.06 \mathrm{pg} / \mathrm{ml})$ more than 13 years. Testosterone level in patients was significantly different $(\mathrm{P}<0.001)$ respectively from the control group. The mean of testosterone level was $1.22 \pm 0.83 \mathrm{ng} / \mathrm{ml}$ in thalassemia patients and $3.71 \pm 1.32 \mathrm{ng} / \mathrm{ml}$ in control group more than 14 years. These results indicate high prevalence hypothyroidism and puberty defection. Endocrine drugs supplementation is a safe for patients which have each type of endocrine disorders.
\end{abstract}

KEYWORDS: $\beta$-Thalassemia; FT4, TSH ; Estradiol; Testosterone

\section{INTRODUCTION}

Thalassemia is the common genetic disorder on a worldwide basis (Cao and Galanello,2010). Most of these patients are born in developing and low-income countries, specially; individuals originate from Mediterranean, Middle East, Asian subcontinent and Southeast Asia (Weatherall and Clegg, 2001; Cao and Kan,2013). Thalassemia has been studied in various cities and different fields in Iraq (AlSamarrai et al., 2008; Abdulzahraa et al., 2011; Al-Hakeim et al., 2015).

$\beta$-Thalassaemia major is a type of chronic, inherited and microcytic anaemia that is characterized by impaired biosynthesis of the $\beta$-globin chain of haemoglobin that lead to accumulation of unpaired $\alpha$-globin chain. Excess presence of the $\alpha$-globin in chains lead to impaired erythropoiesis and is the primary reason for the cellular oxidative damages (Mahdi , 2014).

Blood transfusion and iron chelation therapy have improved the quality of life and life-span to an around 30 years (Telfer et al.,2009). Unfortunately repeated blood transfusions and increased gastrointestinal iron absorption lead to progressive iron overload in patients with $\beta$-thalassemia major disease (Bhat et al.,2013).The progressive iron overload causes ineffective erythropoiesis, gastrointestinal absorption of iron and lack of physiologic mechanism for excreting the excess iron which results in hemochromatosis (Sagare and Trivedi, 2014).Iron deposits as hemosiderin and ferritin in the liver, spleen and many glands. Ferritin is used as a indicator for iron overload disorders (Chirico et al., 2015). Therefore, require chelation therapy, adequate dosage decreases detoxifies iron and iron-related complications and improves quality of life and overall survival (Olivieri and Brittenham,
1997). Unfortunately, iron overload may develop endocrine complications such as growth retardation, failure of sexual maturation, diabetes mellitus, insufficiency of the parathyroid, thyroid, pituitary and less commonly adrenal gland (BorgnaPignatti and Galanello, 2004; Galanello and Origa , 2010).

The frequency of hypothyroidism in $\beta$-thalassemia patients changes between 6 to $30 \%$ in the different countries depending on chelation regimens (Sanctis, et al., 2004). Thyroid dysfunction was defined on the following: overt hypothyroidism (low free thyroxine [FT4] and increased thyroid-stimulating hormone levels $>5 \mu \mathrm{IU} / \mathrm{ml}$ ); subclinical hypothyroidism (normal level to theFT4 and TSH between $5-10 \mu \mathrm{IU} / \mathrm{ml}$ ) and central hypothyroidism (low FT4 and normal or decreased TSH (Soliman et al., 2013).

All studies have confirmed that the prevalence of hypogonadism in the adult $\beta$-thalassemia patients is very high (Tiosano and Hochberg, 2001; Merchant et al., 2011; Sharaf et al.,2014). Impaired puberty in $\beta$-thalassemia patients include delayed puberty, arrested puberty and hypogonadism. Delayed puberty is described as the absence of breast development in girls and testicular enlargement in boys by the age of 13 and 14 year respectively. Arrested puberty is defined as the absence of pubertal growth for more than one year after puberty onset, where testicular volume in boys is less than $68 \mathrm{ml}$ and unchanged breast size in girls (Kyriakou \& Skordis, 2009).

\section{MATERIAL AND METHOS}

The study was undertaken in the Thalassemia Center in Duhok from $1^{\text {st }}$ November to $30^{\text {th }}$ September in 2014 to 2015.ThirtyEight patients with $\beta$ - thalassemia major were selected that aged between 10-20 years with average (13.34 \pm 2.7$), 18$ girls and 20 boys from the Duhok Thalassemia Center. For the maintaining

* Corresponding author

This is an open access under a CC BY-NC-SA 4.0 license (https://creativecommons.org/licenses/by-nc-sa/4.0/) 
the hemoglobin $(\mathrm{Hb})$ levels above $9 \mathrm{~g} / \mathrm{dl}$, all patients were under regular transfusion program $(200 \mathrm{ml}$ packed $\mathrm{RBCs} / \mathrm{kg}$, at 4-5 weeks interval). Additionally, all patients received the folic acid and iron chelating drug like the Deferasirox or deferoxamine (desferal) supplements.. Deferasirox is oral route drug with half-life of up to 16 hours, hence once daily dose is acceptable to maintain an effective plasma level of the drug. Other drug is Deferoxamine, subcutaneous infusion route use for removing extra iron precipitation over 8-12 hours in 5 to 7 days each week.

Also, thirty-eight healthy persons with the meaning age $14.08 \pm 3.02$ years ( 21 girls and 17 boys) participated in the study as the control group with their age range comparable to that of the patients. None of healthy persons have anaemic or systemic disease.

Blood sample were collected from $38 \beta$-thalassemia patients and 38 healthy individuals. Samples were taken from the patients prior to the blood transfusion to avoid possible measurement of exogenously transfused hormones. Then blood samples were transferred into labelled tubes and centrifuged. Serum was collected for further analysis in polythene tube and stored at $-20{ }^{\circ} \mathrm{C}$.

Level of the serum FT4, TSH, Estradiol and Testosterone were studied by enzyme linked fluorescent assay method employing VIDAS instrument (Biomerifux, France) based on an immunoenzymetic method (enzyme linked flouresnt assay). The mean level of the estradiol and testosterone were correlated with the pubertal stage of the patients and healthy persons.

Data were analyzed statistically by Graph Pad Prism 5 by using $t$ test. $\beta$ - Thalassemia major patients were compared with control group. Results were expressed as mean \pm standard deviation and P-values $<0.05$ were measured statistically significant and pointed as *.

\section{RESULTS}

Table 1. shows the different levels of parameters between $\beta$ thalassemia major patients and control group. The two groups had no significant differences in ages.

Table 1. shows the comparison levels of thyroid parameters between $\beta$-thalassemia patients and control group

\begin{tabular}{|c|c|c|c|}
\hline \multicolumn{1}{|c|}{ Petween $\beta$-thalassemia patients and control group } \\
\hline $\begin{array}{c}\text { Age( years }) \\
\text { Female } \\
\text { Male }\end{array}$ & $\begin{array}{c}13.34 \pm 2.74 \\
21 \\
(\mathrm{n}=38)\end{array}$ & $\begin{array}{c}\beta- \\
14.08 \pm 3.02 \\
18 \\
\text { Mean } \pm \text { SD } \\
(\mathrm{n}=38)\end{array}$ & PS-value \\
\hline $\begin{array}{c}\text { FT4 } \\
(\mathrm{pmol} / \mathrm{l})\end{array}$ & $13.13 \pm 1.23$ & $13.47 \pm 1.56$ & $\mathrm{NS}$ \\
\hline $\begin{array}{c}\mathrm{TSH} \\
(\mu \mathrm{IU} / \mathrm{ml})\end{array}$ & $2.72 \pm 1.01$ & $3.86 \pm 2.71$ & $\mathrm{p}<0.05$ \\
\hline
\end{tabular}

Figure 1. indicates the comparison of FT4 assay in the patients and control group. The mean FT4 level was $13.47 \pm 1.56 \mathrm{pmol} / 1$ in $\beta$-thalassemia major patients and $13.13 \pm 1.23 \mathrm{pmol} / \mathrm{l}$ in control group. There was no significant variation between patients and control group.

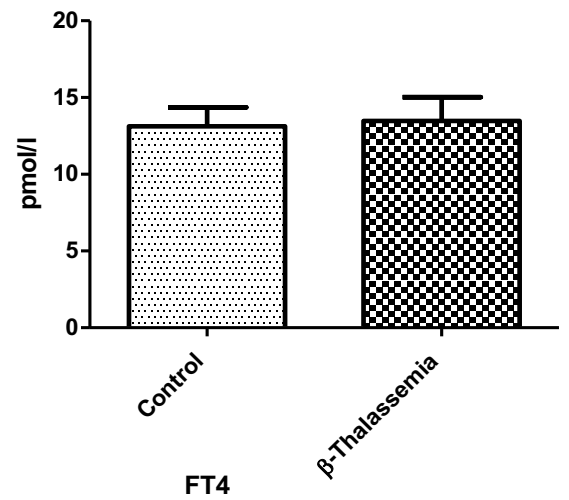

Figure 1. Comparison of the average of FT4 in the patients and control group.

Figure 2. represents the comparison of TSH level in patients and control group. The mean TSH level was $3.86 \pm 2.71 \mu \mathrm{IU} / \mathrm{ml}$ in patients and $2.72 \pm 1.01 \mu \mathrm{IU} / \mathrm{ml}$ in control group. TSH level was significantly higher in patients group as compared with control group $(\mathrm{p}<0.05)$ and 23.68 percentage $(9 / 38)$ from $\beta$-thalassemia major patients had elevated TSH levels that indicating primary subclinical hypothyroidism.

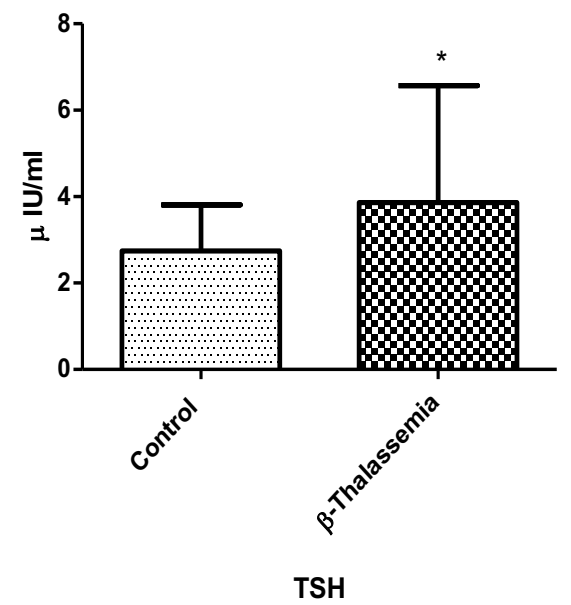

Figure 2. Comparisons of TSH levels among different study groups.

Table 2. is showing the comparison of the mean of the Estradiol level between patients and control group

\begin{tabular}{|c|c|c|c|}
\hline $\begin{array}{c}\text { Parameters } \\
\text { Female }>13 \\
\text { years }\end{array}$ & $\begin{array}{c}\text { Control } \\
\text { Mean } \pm \text { SD } \\
\mathrm{n}=12\end{array}$ & $\begin{array}{c}\beta \text {-Thalassemia } \\
\text { Mean } \pm \text { SD } \\
\mathrm{n}=14\end{array}$ & P-value \\
\hline $\begin{array}{c}\text { Estradiol } \\
(\mathrm{pg} / \mathrm{ml})\end{array}$ & $30.60 \pm 14.68$ & $13.82 \pm 9.06$ & $\mathrm{p}<0.01$ \\
\hline
\end{tabular}

Figure 3. is showing the comparison of estradiol assay in patients and control group with female ages more than 13 . The mean levels were $30.60 \pm 14.68 \mathrm{pg} / \mathrm{ml}$ in $\beta$-thalassemia patients and $13.82 \pm 9.06 \mathrm{pg} / \mathrm{ml}$ in control group. Mean of the estradiol was significantly lower in $\beta$-thalassemia major patients group than in control group $(p<0.01)$ and 64.28percentage $(9 / 14)$ from the $\beta$ thalassemia patients have low level of the estradiol comparison the normal level of estradiol that results were less than $18 \mathrm{pg} / \mathrm{ml}$. 


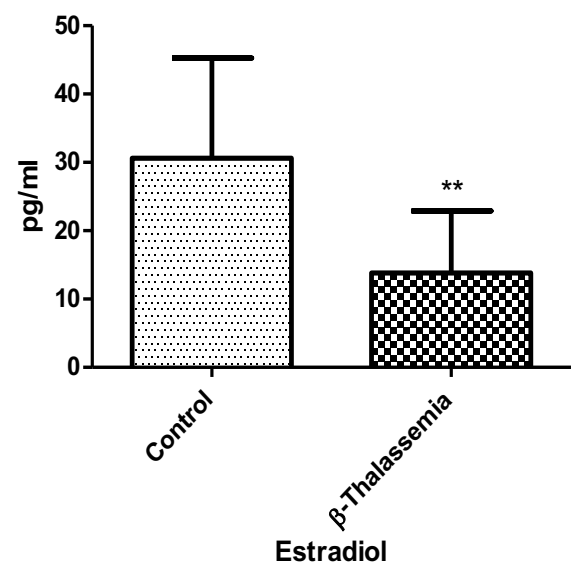

Figure3. is the comparison of the mean level of the Estradiol in the patients and control group.

Table 2. shows the comparison of the mean level of the testosterone between the two group

\begin{tabular}{|l|l|l|l|}
\hline Parameters & $\begin{array}{l}\text { Control } \\
\text { Mean } \pm \text { SD }\end{array}$ & $\begin{array}{l}\beta \text {-Thalassemia } \\
\text { Mean } \pm \text { SD }\end{array}$ & P-value \\
$\begin{array}{l}\text { Male }>14 \\
\text { years }\end{array}$ & $\mathrm{n}=7$ & $\mathrm{n}=9$ & \\
\hline $\begin{array}{l}\text { Testosterone } \\
(\mathrm{ng} / \mathrm{ml})\end{array}$ & $3.71 \pm 1.32$ & $1.22 \pm 0.83$ & $\mathrm{p}<0.001$ \\
\hline
\end{tabular}

Figure 4. is showing the mean testosterone level was $1.22 \pm$ $0.83 \mathrm{ng} / \mathrm{ml}$ in patients and level in the control group $3.71 \pm$ $1.32 \mathrm{ng} / \mathrm{ml}$ more than 14 years. There was highly significant decreases in the mean of serum testosterone in $\beta$-thalassemia major patients than incontrol group $(\mathrm{p}<0.001)$ and 77.77 percentage (7/9) from the patients have low level from the normal value $(2.27-10: 30 \mathrm{ng} / \mathrm{ml})$.

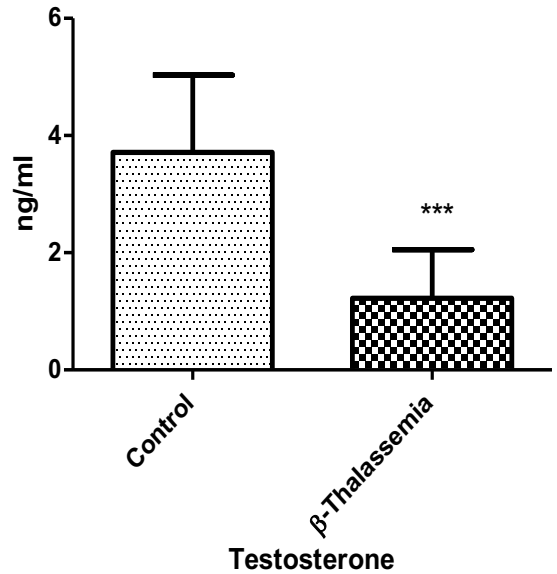

Figure 4. is showing the different mean level of testosterone in $\beta$-thalassemia patients and control group.

\section{DISCUSSION}

Multiple transfusions and Iron overload are the main reason of complications, such as impairment in the functions of thyroid gland although patients with thalassemia major require repeated blood transfusions (Berkovitch et al., 2000). Our study illustrated that the mean of the FT4 in the patients was in normal range compared with control group, whereas
TSH level in the patients was significantly higher than control group.

Jain (1995) reported the mean serum total T4 and T3 levels in the $\beta$-thalassemia patients were lower significantly $(\mathrm{p}<0.001)$ and TSH level was higher than control group. Other study was demonstrated significant $(\mathrm{p}<0.05)$ increased TSH $(3.5 \pm 1.7$ $\mu \mathrm{IU} / \mathrm{ml})$ in the thalassemia patients, when comparison with healthy control group $(2 \pm 1.2 \mu \mathrm{IU} / \mathrm{ml})$, those results showed $20 \%$ with subclinical hypothyroid (Salih and Al-Mosawy, 2013). Similarly, other study showed that in the $\beta$-thalassemia patients, level of T4 was lower than the control group and TSH level was higher than the control group(Asad et al., 2016).

Our study was shown that 23.68percentages from $\beta$-thalassemia patients had subclinical hypothyroidism, which was in good agreement with the study by Malik et al (2010).Additionally, our findings and conclusions disagree with Mula-Abed et al. (2008) and Pirincciogla et al (2011) that the prevalence was 3.3\%. In Baghdad, it was illustrated that 12 out of 60 patients with hypothyroidism (20\%) and seven patients $(12 \%)$ had subclinical hypothyroidism. Whereas, five of patients $(8 \%)$ suffer from primary or overt hypothyroidism(Hassan et al., 2013). Recent study by Ayoub et al (2016) demonstrated prevalence of hypothyroidism $21.9 \%$ of $\beta$-thalassemia patients in Baghdad (high TSH level with normal T4) in their study subjects. Even so, secondary hypothyroidism was rare in $\beta$-thalassemia patients, which was not observed. Ghosh (2008) reported the prevalence of Subclinical hypothyroidism about $23.5 \%$ in West Bengal. Another study showed that progressive of thyroid dysfunction observed about $35 \%$ of $\beta$-thalassemia patients who have the age 18. The lack of elevated of TSH in response to low levels of T4 in these patients was indicated a high incidence of defective pituitary thyrotrophic function (Soliman et al., 2013).

However, the variation of prevalence may be related to the age of study population, duration of blood transfusions, ferritin levels and dose of the iron-chelating agent (Aydinok et al., 2002; Zervas et al., 2002). In this study, hypothyroidism was $23.68 \%$ of $\beta$ thalassemia patients which depending on the elevation of thyroid stimulating hormone more than $5 \mu \mathrm{IU} / \mathrm{ml}$. High prevalence ranges in our study may be contributed to several repeated transfusion and poor iron chelation therapy. Moreover, Iraq has many economic and security problems mainly deficiency of the quality in the equipment and drugs causes increasing these complications.

Considerable mechanisms for thyroid dysfunction in $\beta$ thalassemia patients have been suggested, nevertheless, the exact mechanism is not known. Hypothyroidism may be related to the accumulation of iron in thyroid glands due to blood transfusion by iron overload leading to gland dysfunction (Fung et al., 2006).Consequently, the iron stored as ferritins deposited in organs as hemosiderin, a toxic substance affecting tissues at least partially by inducing oxidative stress (Shizukuda et al., 2007). Additionally, formation of free radical and lipid peroxidation were caused to the damage of the mitochondrial, lysosomal, sarcolemma membrane and DNA (Lekawanvijit and Chattipakorn, 2009; Hershko, 2010). Those damages involve practically all organs in the body like spleen, liver and bone narrow. Also, iron poisoning effects on several endocrine glands as the thyroid gland function and gonads (Berkovitch et al.,2000). Most thalassemia patients have a delayed or absent puberty occur with appearance disorder in menstrual cycle and anovulation in women. Also, Sperm abnormalities happen and reduce sexual activity in males. In the different studies, the incidence rate of the puberty failure was between $50 \%$ to $100 \%$ (Tiosano and Z Hochberg, 2001; Moayeri and Oloomi, 2006).

This our study indicated that female more 13 years, the level of estradiol $(30.60 \pm 14.68 \mathrm{pg} / \mathrm{ml})$ declined high significant $(\mathrm{p}<0.01)$ compared with control group $(13.83 \pm 9.06 \mathrm{pg} / \mathrm{ml})$ whereas the mean of testosterone level was $1.22 \pm 0.83 \mathrm{ng} / \mathrm{ml}$ in $\beta$-thalassemia patients and $3.71 \pm 1.3 \mathrm{ng} / \mathrm{ml}$ in control group more than 14 years. Mean level of testosterone was highly significantly lower in $\beta$ - 
thalassemia patients than in control $(\mathrm{p}<0.001)$.In $\beta$ thalassemia patients low level estradiol (in females) and testosterone (in males) was noted $9 / 14(64.28 \%)$ and $7 / 9$ $(77.77 \%)$ respectively.

Dundar et al (2007) were recorded the serum level of estradiol $19.4 \pm 15.9 \mathrm{pg} / \mathrm{ml}$ reduced significantly $(\mathrm{p}<0.001)$ in the $\beta$-thalassemia patients compared with control group $(72.1 \pm 51.1 \mathrm{pg} / \mathrm{ml})$ in puberty females, and in the males, serum levels of testosterone reduced in the $\beta$-thalassemia patients but not statistically significant. Carmina et al (2004) reported the serum level of testosterone $(66 \pm 123.66 \mathrm{ng} / \mathrm{ml})$ in $\beta$-thalassemia patients significant decrease with healthy group $(331.98 \pm 173.76 \mathrm{ng} / \mathrm{ml})$ in the male aged 14-18years . Other finding indicated lower serum levels of estradiol than controls of similar age. Additionally, Hegazi et al (2013)were compared the mean of the serum level of estradiol of patients with control group in the female aged between12.5-18 years. The results indicated significant $(p<0.05)$ decreased the level of estradiol $(22.91 \pm 17.41 \mathrm{pg} / \mathrm{ml})$ in the patients, when comparison with control group $(108.17 \pm 107.45 \mathrm{pg} / \mathrm{ml})$.

Sexual immaturity is the most complication of severe thalassemia. The association between hypogonadism and pituitary iron overload is well established, begins in the first decade of life, duo to pituitary iron overload prior to the liver and cardiac iron deposition (Au et al., 2009; Noetzli et al., 2012). Pituitary iron overload and iron-induced oxidative stress may result in secondary hypogonadism in thalassemia patients (Roussou et al., 2013).

\section{CONCLUSION}

Endocrine problems are the important abnormality states in the second decade of the beta-thalassemia major patient's life. Progressive accumulation of iron overload in some glands causes interruption of the hormone metabolism through ruining the gland structure and disturbing the energy availability required for hormone synthesis. Regular followup and appropriate endocrine treatments are suggested. We should focus our attention to chation therapy program which controls the negative effects of the iron overload in the many endocrine gland.

Additionally, antioxidant drugs, like the vitamin $\mathrm{C}$ and zinc are recommended which may reduce negative side effects of the iron overload, oxidative stress and tissue damage.

\section{ACKNOWLAGMENT}

The authors would like to thank the staff of the Thalassemia Center and Hivi Hospital and Duhok Central Laboratory for their assistance and cooperation.

\section{REFERENCES}

Abdulzahraa, M.S., Al-Hakeim, H.K and Ridha, M.M.(2011) Study of the effect of iron overload on the function of endocrine glands in male thalassemia patients.Asian $J$ Trans Sci.,vol. 5, pp. 127-131.

Al-Hakeim, H. K., Al-Khakani M. M and Al-Kindi, M.A.(2015).Correlation of Hepcidin Level with Insulin Resistance and Endocrine Glands Function in Major Thalassemia. AdvClinExp Med., vol.24, pp. 69-78.

Al-Samarrai, A.H ., Adaay, M.H., Al-Tikriti, K.A., Al-Anzy, M.M.(2008). Evaluation of some essential element levels in thalassemia major patients in Mosul district Iraq.Saudi Med J, vol.29, pp. 94-97.

Asad, Z.T., Ghazanfari, M., Naleini, S.N., Sabagh, A and Kooti, W.(2016). Evaluation of serum levels in T3 T4 and TSH in beta-thalassemic patients referred to the Abuzar hospital in Ahwaz. Electron Physician, vol.8,pp. 2620-4.

Au, W.Y., Lam, W.W., Chu, W.W., Yuen, H.L., Ling, A.S., Li RC et al.(2009).A cross sectional magnetic resonance imaging assessment of organ specific hemosiderosis in 180 thalassaemia major patients in Hong Kong. Haematologica, vol.93, pp.784-6.

Aydinok, Y., Darcan, S., Polat, A., Kavakli, K., Nigli, G., Coker, M., Kantar, $M$ and Cetingul, N.(2002 ). Endocrine complications in patients with b-thalassemia major. Journal of Tropical Pediatrics, vol.48, pp. 50-54.

Ayoub, N., Khaleel., K. J and Mohammed, I.I.(2016). Hypothyroidism in transfusion dependent $\beta$-thalassemia. Iraqi Journal of Cancer and Medical Genetics, vol. 9, pp. 36-39.

Berkovitch, M., Bistritzer, T., Milone, S.D., Perlman, K., Kucharczyk, W and Olivieri, N.F.(2000). Iron deposition in the anterior pituitary in homozygous beta-thalassemia: MRI evaluation and correlation with gonadal function. $J$ PediatrEndocrinolMetab., vol.13, pp.179-84.

Bhat, A., Parwani, R., NandWanjari, S. P.(2013). Demonstration of iron in exfoliated buccal cells of $\beta$-thalassemia major patients. $\mathrm{J}$ Cytol.,vol. 30, pp,169-173.

Borgna-Pignatti, C and Galanello, R(2004). Thalassemia and related disorders: quantitative disorders of hemoglobin synthesis. In introbe's Clinical Hematology, eleven th edition: Lippincott Williams \& Wilkins. Philadelphia, 1319-65.

Cao, A and Kan, Y. W.(2013). The Prevention of Thalassemia. Cold Spring HarbPerspect Med., vol.3, pp. a011775. doi: $10.1101 /$ cshperspect.a011775.

Cao, A and Galanello, R.(2010). Beta-thalassemia. Genetics in Medicin., vol.12, pp. 61-76.

Carmina, E., Di Fede, G ., Napoli, N., Renda, G ., Vitale, G., Lo, P.C., Bruno, D., Malizia, R and Rini, G.B.(2004). Hypogonadism and hormone replacement therapy on bone mass of adult women with thalassemia major. Calcif Tissue Int., vol.74, pp.68-71.

Chirico, V., Rigoli, L., Lacquaniti, A.., Salpietro, V., Piraino, B et al.(2015). Endocrinopathies, metabolic disorders, and iron overload in major and intermedia thalassemia: Serum ferritin as diagnostic and predictive marker associated with liver and cardiac T2* MRI assessment. Eur J Haematol., vol. 94, pp. 404-412.

De Sanctis, V., Eleftheriou, A and Malaventura, C.(2004). Prevalence of endocrine complications and short stature in patients with thalassemia major: a multicenter study by the Thalassemia International Federation (TIF). PediatrEndocrinol Rev., vol2, pp. 249-55.

Dundar, U., Kupesiz, A., Ozdem, S., Gilgil, E ., Tuncer, T., Yesilipek, A and Gultekin, M.(2007). Bone metabolism and mineral density in patients with beta-thalassemia major. Saudi Med J., vol. 28, pp.1425-9.

Fung, E., Harmatz, P.R and Lee P.D et al.(2006). Increased prevalence of iron overload associated endocrinopathy in thalassaemia versus sickle cell disease.Br J Haematol., vol.135, pp.574-82.

Galanello, R and Origa,v.(2010). Beta-thalassemia. Orphanet $J$ Rare Dis., vol. 5,pp11.

Ghosh, S., Bandyopadhyay, S.K., Bandyopadhyay, R., Roy, D., Maisnam, I and Ghosh, M.K..(2008). A study on endocrine dysfunction in thalassaemi., J Indian Med Assoc., vol. 106, pp. 655-6, 658-9.

Hassan, NAR ., Musa, RJ and Abdullah, SA.(2013). Effect of Iron overload and lipid peroxidation on thyroid function in Iraqi patients with ß-Thalassemia. Asian Journal of Applied Sciences, vol.1, Issue.

Hegazi, M. A.M., Obada, M.A and Elsheashaey, A.M.(2013). Effect of Iron Overload on Function of Endocrine Glands in Egyptian Beta Thalassemia Patients. Journal of Applied Sciences Research, vol. 9, pp.4656-4662.

Hershko, C.(2010). Pathogenesis and management of iron toxicity in thalassemia. Ann N Y Acad Sci., vol. 1202, pp.1-9.

Jain, M., Sinha, R.S., Chellani, H and Anand, N.K.(1995). Assessment of thyroid functions and its role in body growth in thalassemia major. Indian pediatr., vol.32, pp. 213-9. PMID: 8635784.

Kyriakou, A and Skordis, N.(2009). Thalassaemia and aberrations of growth and puberty. Mediterr J Hematol Infect Dis., vol.1,pp. e2009003.

Lekawanvijit, S and Chattipakorn, N.(2009). Iron overload thalassemic cardiomyopathy: Iron status assessment and mechanisms of mechanical and electrical disturbance due to iron toxicity. Can J Cardiol., vol. 25, pp.213-218.

Mahdi, E. A.(2014). Relationship between Oxidative Stress and Antioxidant Status In Beta Thalassemia Major Patients. ActaChim. Pharm. Indica., vol.4, pp.137-145. 
Malik, S.A., Syed, S and Ahmed, N.(2010).Frequency of hypothyroidism in patients of beta-thalassemia. $J$ Pak Med Assoc., vol. 60,pp.17-29.

Merchant, R.H., Shirodkar, A and Ahmed, J. (2011). Evaluation of growth, puberty and endocrine dysfunctionsin relation to ironoverload in multi transfus ed Indian thalassemia patients. Indian JPediatr., vol, pp. 679-83.

Moayeri, H and Oloomi , Z.(2006). Prevalence of growth and puberty failure with respect to growth hormone and gonadotropins secretion in beta-thalassemia major. Arch Iran Med., vol,9, pp.329-34.

Mula-Abed, W., Al-Hashimi, H., Al-Muslahi, M., Al-Muslahi, H and Al-Lamki, M.(2008).Prevalence of Endocrinopathies in patients with beta-thalassemia major a cross-sectional study in Oman. Oman Med., vol. 23, pp.257-261.

Noetzli L.J, Panigrahy A, Mittelman S.D, Hyderi A, Dongelyan A, Coates TD et al.(2012). Pituitary iron and volume predict hypogonadism in transfusional iron overload. $\mathrm{Am} \mathrm{J}$ Hematol., vol 87, pp.167-71.

Olivieri, N. F and Brittenham, GM.(1997). Iron-chelating therapy and the treatment of thalassemia. Blood, vol,89, pp.73961.

Pirinccioglu, A ., Deniz, T., Gokalp, , D., Beyazit, N., Haspolat, K and Soker, M .(2011).Assessment of thyroid function in children aged $1-13$ years with beta - thalassemia major. Iran J. pediatr., vol. 21,pp. $77-82$.

Roussou, P., Tsagarakis, N.J ., Kountouras, , D., Livadas, S and Diamanti-Kandarakis, E. (2013). Beta-thalassemia major and female fertility: the role of iron and iron induced oxidative stress. Anemia. 617204

Sagare, A and Trivedi, D. J .(2014). Assesment of Transferrin Saturation as an Indicator of Iron Overload in
Homozygous \&Hetrozygous Form of Thalassemia. Research Journal of Pharmaceutical. Biological and Chemical Sciences, vol. 5, pp. 669- 673 .

Salih, K. M and Al-Mosawy, W. F.(2013). Evaluation Some Consequences Of Thalassemia Major In Splenectomized And Non-Splenectomized Iraqi Patient. Int J Pharm Pharm Sci., vol.5, pp. 385-388.

Sharaf, A. E. A., Ali, S. H and Abo-Elwafa, H. A.(2014). Evaluation of puberty in relation to iron overload in multi transfused Bthalassemia patients. Journal of American Science, vol.10, pp. 1-7.

Shizukuda, Y., Bolan, C.D and Nguyen, T et al.(2007). Oxidative stress in asymptomatic subjects with hereditary hemochromatosis, Am J Hematol., vol. 82 , pp.249-250.

Soliman, A., Al Yafei, F., Al-Naimi, , L., Almarri, N., Sabt, A and Yassin, $M$ et al.(2013):Study on linear growth and thyroid function for 12 years in patients with $\beta$ thalassemia major.Endocrine, vol.32,pp.992

Telfer, P. T., Warburton, F., Christou, S., Hadjigavriel, M., Sitarou, M and Kolnagou, A.(2009).Improved survival in thalassemia major patients on switching from desferrioxamine to combined chelation therapy with desferrioxamine and deferiprone. Haematologica., vol.94, pp 1777-8.

Tiosano, D and Hochberg, Z,(2001). Endocrine Complications of Thalassemia. Journal of Endocrinological Investigation, vol.24, pp716-723

Weatherall, D.J and Clegg, J.B.(2001). The Thalassemia syndromes fourth edition. United Kingdom: Blackwell Science.

Zervas, A., Katopodi, A., Protonotariou, A., Livadas, S., Karagiora, M. Politis, C and Tolis, G .(2002). Assessment of thyroid function in two hundred patients with $\beta$-thalassemia major. Thyroid, vol. 12, pp. 151-154. 